\title{
Progress in knowledge of Alzheimer's disease
}

\author{
Julio López Argüelles ${ }^{1 *}$, Dra Leydi M Sosa Aguila ${ }^{2}$, Lic Aleima B Rodriguez Carbajal ${ }^{3}$ and Lisan Montalvo \\ Manso $^{1}$ \\ ${ }^{1}$ Department of Neurology, University Hospital Gustavo Aldereguía Lima, Cuba \\ ${ }^{2}$ Genetic Center, University Hospital Paquito González Cueto, Cuba
}

${ }^{3}$ Department of Neuropsychology, University Hospital Gustavo Aldereguía Lima, Cuba

*Corresponding author: Julio López Argüelles, Department of Neurology,

University Hospital Gustavo Aldereguía Lima, Cuba.

Received Date: July 25, 2019

Published Date: July 29, 2019

\begin{abstract}
In the old age increase the frequencies of mental disease such as primary dementias, being presented most frequently Alzheimer's Disease and vascular dementia. The principal progress is based on the determination of the early presence of changes in the patients genetically predisposed to suffer from Alzheimer's disease, studies endorsed by a monitoring to patients with mutations from 1 to 3 genes associated with Alzheimer's disease of early appearance. For first time we got a chronological table of the events that indicate the need for early intervention, with available biological markers that can be measured in order to evaluate the effects of the pharmacotherapy.
\end{abstract}

Keywords: Dementia; Alzheimer's disease; Biological marker; Beta protein amyloide

\section{Introduction}

With the preludes of the 21st century aging has reached in our country a significant splendor, due to the steady increase of the elderly population. In the old age increase the frequencies of mental disease such as primary dementias, being presented most frequently Alzheimer's Disease and vascular dementia [1,2]. Dementias constitute a serious problem of public health, to be a high economic and social cost, by what is difficult and late of its diagnosis and by its incapacitating course progressive. The number of people with dementia, at the world level, grows rapidly and the figures demonstrate it because in only 25 years, 34 million people will suffer dementia [3,4].

\section{Development}

The principal progress is based on the determination of the early presence of changes in the patients genetically predisposed to suffer from Alzheimer's disease, studies endorsed by a monitoring to patients with mutations from 1 to 3 genes associated with Alzheimer's disease of early appearance. Of the family histories could be calculated the average of the age at the beginning (characteristically to the 40 years) and then looked at the carriers of younger genes, and investigated the sequence of the changes of the biological marker that occurred before dementia, found that:
- 20 years before the onset of the disease, the levels of betaamyloid in the cerebrospinal fluid begins to increase,

- 15 years before the beginning of dementia, se detect diagnostic imaging deposits of beta amyloid by scaners, the levels of the protein tau begins to increase in the cerebrospinal fluid and begins to appear the atrophy in the magnetic resonance,

- 10 years before the beginning of dementia, the metabolic changes appear through PET and begin the first signs of alteration of the memory,

- 10 years before the beginning of dementia, the patients begin with moderate cognitive deterioration.

From the foregoing have first time, a chronological table of the events that indicate the need for early intervention, with available biological markers that can be measured in order to evaluate the effects of the pharmacotherapy [5,6]. Another important progress is the finding of a mutation in approximately 1 of 100 Islandeces who can reduce the risk for Alzheimer's disease of 5-7 times in comparison with the general population. The mutation occurs in the gene of the protein of precursor of amyloid and seems to interfere 
with the capacity of the beta-secretasa to act in the division of the APP, inhibiting the creation of the beta protein amyloide. The levels of the protein betaamiloide are reduced nearly $40 \%$ in the individuals with this mutation. This study represents a natural experiment that confirms for the first time that the low levels of betaamiloide are associated with smaller risk for Alzheimer's disease and can extend the development of drugs in their assistance $[7,8]$.

With these results become evident a renewed and growing interest in the pharmaceutical companies and the academic community in the development of inhibitors of the beta-secretasa that retard or modify therapies for Alzheimer's disease. Example of stated the foregoing is the existence of association between researchers and pharmaceutical industries as Merck, Eli Lilly and Company, and Eisai Pharmaceuticals that study a drug candidate, suggesting (at least preliminarily) its safety and its capacity to penetrate the central nervous system, and reliable dose in order to decrease the levels of beta-amyloide, potentially to 50\%-90\%. These results give the hope that 1 or more of these oral agents can turn out utensils as therapy in order to modify the disease.

\section{Acknowledgement}

None.

\section{Conflict of Interest}

There was no conflict of interest in the research governance and conduct of the research, nor in the reporting arrangements.

\section{References}

1. Peng D, Shi Z, Xu J, Shen L, Xiao S, et al. (2016) Demographic and clinical characteristics related to cognitive decline in Alzheimer disease in China: A multicenter survey from 2011 to 2014. Medicine (Baltimore) 95(26): e3727.

2. Alagiakrishnan K, Gill SS, Fagarasanu A (2012) Genetics and epigenetics of Alzheimer's disease. Postgrad Med J 88(1043): 522-529.

3. Haines JL (2018) Alzheimer Disease: Perspectives from Epidemiology and Genetics. J Law Med Ethics 46(3): 694-698.

4. Kuller LH (2018) A new era for dementia epidemiology: Alzheimer's disease, hardening of arteries, or just old age? Eur J Epidemiol 33(7): 613-616.

5. Bateman RJ, Morris JC (2014) A New Era: Disease Modifying Alzheimer Disease Prevention Trials. J Prev Alzheimers Dis 1(2): 68.

6. Bussy A, Snider BJ, Coble D, Xiong C, Fagan AM, et al. (2019) Effect of apolipoprotein $\mathrm{E} 4$ on clinical, neuroimaging, and biomarker measures in noncarrier participants in the Dominantly Inherited Alzheimer Network. Neurobiol Aging 75: 42-50.

7. Desikan RS, Schork AJ, Wang Y, Thompson WK, Dehghan A, et al. (2015) Polygenic Overlap Between C-Reactive Protein, Plasma Lipids, and Alzheimer Disease. Circulation 131(23): 2061-2069.

8. Moskvina V, Harold D, Russo G, Vedernikov A, Sharma M, et al. (2013) Analysis of genome-wide association studies of Alzheimer disease and of Parkinson disease to determine if these 2 diseases share a common genetic risk. JAMA Neurol 70(10): 1268-1276. 